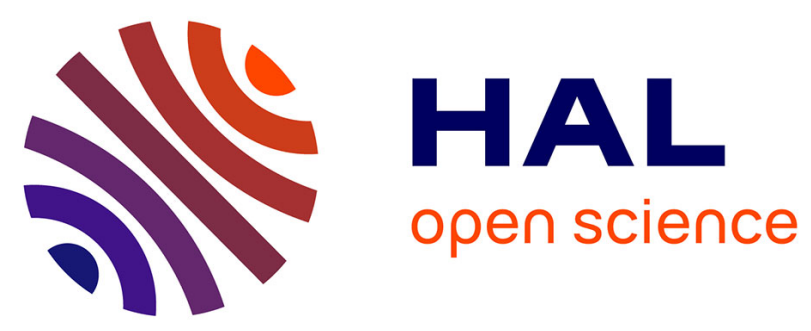

\title{
Risk assessment of sensory irritants in Indoor air - A case study in a French School
}

\author{
Roman Meininghaus, Amin Kouniali, Corinne Mandin, André Cicolella
}

\section{To cite this version:}

Roman Meininghaus, Amin Kouniali, Corinne Mandin, André Cicolella. Risk assessment of sensory irritants in Indoor air - A case study in a French School. Environment International, 2003, 28 (7), pp.553-557. 10.1016/S0160-4120(02)00063-6 . ineris-00961878

\section{HAL Id: ineris-00961878 \\ https://hal-ineris.archives-ouvertes.fr/ineris-00961878}

Submitted on 20 Mar 2014

HAL is a multi-disciplinary open access archive for the deposit and dissemination of scientific research documents, whether they are published or not. The documents may come from teaching and research institutions in France or abroad, or from public or private research centers.
L'archive ouverte pluridisciplinaire HAL, est destinée au dépôt et à la diffusion de documents scientifiques de niveau recherche, publiés ou non, émanant des établissements d'enseignement et de recherche français ou étrangers, des laboratoires publics ou privés. 
Risk Assessment of Sensory Irritants in Indoor Air - A Case

\section{Study in a French School}

Roman Meininghaus ${ }^{1}$, Amin Kouniali $^{1}$, Corinne Mandin $^{1}$, and André Cicolella ${ }^{1}$

${ }^{1}$ INERIS, Parc Technologique ALATA, F-60550 Verneuil-en-Halatte

Corresponding author: Roman Meininghaus (Tel: 00333445561 99;

Fax:0033 344556302 ; e-mail:roman.meininghaus@ineris.fr) 


\title{
Risk Assessment of Sensory Irritants in Indoor Air - A Case Study in a French School
}

\author{
Roman Meininghaus $^{1}$, Amin Kouniali $^{1}$, Corinne Mandin $^{1}$, and André Cicolella ${ }^{1}$ \\ ${ }^{1}$ INERIS, Parc Technologique ALATA, F-60550 Verneuil-en-Halatte \\ Corresponding author: Roman Meininghaus (e-mail:roman.meininghaus@ineris.fr)
}

\section{Key Words}

airborne sensory irritants; exposure; mixtures; risk assessment; weighted sum parameter

\section{Abstract}

Exposure to airborne pollutants can result in adverse health effects. Acute symptoms can for instance comprise of irritation of the eyes or of the respiratory tract (called sensory irritation). In a recent case, health problems were reported in a French school and supposedly attributed to the presence of airborne irritant pollutants. Based on measured concentrations, the risk of developing the described health effects was assessed. Numerous airborne sensory irritants (aldehydes, organic acids, VOCs, $\mathrm{SO}_{2}, \mathrm{NH}_{3}$ ) were identified and quantified in the indoor air by using active and passive sampling and online monitoring techniques. Reference values based on toxicological properties of compounds (sensory irritants) were taken from the literature. If not available, tentative values were specially developed for this purpose. Concentrations of all sensory irritants remain below their corresponding guideline values and are comparable to literature data. It was concluded that the risk of developing sensory irritation due to the presence of the studied compounds is negligible. This holds both for individual compounds and for the mixture 
of studied compounds. Limitations of the employed sampling strategy, and of existing sampling and analytical techniques, which do not allow for analysing more reactive compounds - which are strong sensory irritants - may play a role. New sampling techniques need to be developed. Psychosocial factors (group behaviour, increased attention to sensory irritation) should also be taken into account when dealing with health complaints on sensory irritation.

\section{Introduction}

Exposure to airborne pollutants can result in adverse health effects. Acute symptoms may for instance comprise of irritation of the eyes or of the respiratory tract (sensory irritation), whereas long-term exposure to certain pollutants may result in more severe effects like asthma or cancer.

The indoor environment plays a substantial role in terms of exposure to airborne pollutants, because people spend most of their time indoors, where pollutant concentrations are often higher than outdoors (Maroni et al., 1995; Nazaroff and Weschler, 2001). Moreover, people are typically exposed to complex mixtures of volatile organic compounds VOCs, with hundred or more different compounds present in the indoor air.

Schools are of special concern when regarding indoor exposure, because children are particularly sensitive to pollutants and spend a significant amount of time in that environment.

In a recent case, health problems were reported in a French school. The symptoms were non-specific (like irritation of the eyes and airways). The hypothesis was formulated that these symptoms might be related to exposure to airborne pollutants. In order to test this hypothesis, a comprehensive measurement protocol was established for the building and numerous airborne compounds were identified and quantified. Based on these results, the risk of developing the described health effects (sensory irritation) due to the pollutants 
was assessed. These experiences are reported here, and the present paper may serve as an example on how to carry out risk assessments of sensory irritants in indoor air.

\section{The Case}

Building: The school - with approximately 80 children and 5 permanent staff - is situated in a small French town within a residential area. It is surrounded by a schoolyard, another school, a small storehouse, and a football ground. The building was constructed about 40 years ago. The site has no industrial history. The building itself consists of three classrooms, a dormitory, a kitchen, a hall, an office, a library, and a storage room. There is no ventilation system installed. The building was carefully inspected with regard to potential chemical and biological emission sources (furniture, household products, water damage, moisture etc.), but no relevant sources were identified.

Health Symptoms: At first, some of the teachers complained about non-specific symptoms like dry sensation of the eyes, irritation of the upper respiratory tract, headaches, and a rough tongue. Later on several children complained about similar problems. The symptoms occurred in different rooms and at different times of the day, but not every day. A correlation with a specific activity inside or outside the building could not be established. Teachers and pupils in the other school nearby (within $50 \mathrm{~m}$ distance) did not complain about similar symptoms.

\section{Sampling Strategy}

Based on the reported health problems, known sensory irritants (aldehydes, organic acids, and the inorganic compounds $\mathrm{SO}_{2}$ and $\mathrm{NH}_{3}$ ) were measured in the air. Additionally, the presence of other VOCs was verified.

Symptoms occurred over relatively short time periods. For this reason, air samples were taken - whenever possible - during episodes when symptoms occurred, either by using online monitoring techniques, or by using grab samplers (canisters). Passive samplers 
were used in order to sample over an extended period of time. The latter technique does not allow for identifying peak concentrations, but high average concentrations may indicate that episodes with high concentrations occurred.

Samples were taken either in most of the rooms (passive samplers) or in the classroom where the highest number of complaints were reported.

As a reduced relative humidity $\mathrm{RH}$ may contribute to eye and airway irritation, $\mathrm{RH}$ was hence measured as well.

$<$ Table 1 should be placed here. >

\section{Methods}

Aldehydes: Passive sampling devices (Radiello ${ }^{\circledR}$, Fondazione Salvatore Maugeri, Padova, Italy (Cocheo et al., 1996)) equipped with dinitrophenyl hydrazine (DNPH) sampling cartridges and ozone scrubbers (Bates et al., 2000), were used to quantify concentrations of the compounds listed in Table 1.

After exposure, the sampling cartridges were extracted with $2 \mathrm{ml}$ acetronitrile. The extracts were analysed with HPLC separation (KROMASIL C18 $150 \mathrm{~mm}-3 \mathrm{~mm}-3.5$ $\mu \mathrm{m})$ and $U V$ detection $(\lambda=365 \mathrm{~nm})$.

The samplers were installed in the classrooms and outdoors (for comparison), and left exposed during 5 days.

Organic Acids: Approximately $1 \mathrm{~m}^{3}$ air was drawn through $50 \mathrm{ml}$ of $0.1 \mathrm{~N} \mathrm{NaOH}$ in order to sample the organic acids listed in Table 1. Compounds were quantified by HPLC separation (analytical column AIT REZEC ACIDE ORGANIQUE $300 \mathrm{~mm}$ ) and UV detection (wavelength $\lambda=210 \mathrm{~nm}$ ). Due to a limited number of sampling devices, these compounds were sampled only in the classroom where most of the complaints were reported, and outdoors (for comparison). 
Volatile Organic Compounds: Other VOCs than aldehydes and organic acids may be responsible for sensory irritation. For this reason, an evacuated grab sampler (passivated Restek $^{(B)}$ canister) was left on site. The sampler was filled with air during a period when health problems occurred, so that potential sensory irritants were trapped. A fraction ( $2 \mathrm{~L}$ ) of the sampled air was then transferred onto a sorption tube (Carbotrap) and analysed by thermodesorption and GC-MS (column DB30, 30m; thermodesorption at $350^{\circ} \mathrm{C}$ during 5 $\min )$.

Inorganic compounds: $\mathrm{SO}_{2}$ was continuously monitored with a UV fluorescence analyser (megatec model 43C) during two days in a classroom where an increased number of complaints had been reported.

Ammonia was sampled on a solid adsorbent coated with $\mathrm{H}_{2} \mathrm{SO}_{4}$ at the same sampling location (sampling volume $30 \mathrm{~L}$, sampling time 10 hours) and analysed by ion chromatography.

Relative Humidity, Temperature: Relative Humidity RH and temperature T were monitored during one week with Tinytalk $^{\circledR}$ measurement devices.

\section{Toxicological Reference Values and Additivity of Effects}

A pollutant at a concentration below its Toxicological Reference Value (TRV) is not considered to represent a risk for the health endpoint studied. Methodologies are available for developing such guideline values base on toxicological properties. For example, for noncarcinogen risk characterisation, safety factors can be used that are applied to the lowest observed adverse health effect (LOAEL) or the no-observed adverse health effect (NOAEL) (Anderson and Albert, 1999). Safety factors take into account inter-species differences (when data are based on animal tests) and intra-species differences (to take into account differences in sensitivity). Other safety factors can account for differences in exposure time (workplace and indoor environment) (Nielsen et al., 1998).

In the present paper, TRV will be selected or developed based on the symptoms of sensory irritation. These symptoms are probably related to short-term (or acute) exposure. 
Acute exposure is usually associated with exposure times between a few minutes and several days.

When dealing with effects of irritation of the upper respiratory tract, values based on a mouse bioassay have been suggested to predict toxic properties of chemicals (Alarie, 1973). The $\mathrm{RD}_{50}$ i.e. the concentration inducing a $50 \%$ decrease in 10 minutes in respiratory rate in mice (found by extrapolation if necessary) is used as a base for comparing irritating potencies of chemicals. It was shown that slight irritation can occur at $0.1 \times \mathrm{RD}_{50}$, and minimal or no effect would occur at $0.01 \times \mathrm{RD}_{50}$. In practice, $0.03 \mathrm{x}$ $\mathrm{RD}_{50}$ has been recommended as a guideline for occupational exposure limits.

In the present case, internationally accepted guideline values (WHO-OMS, 2000) for short-term exposure are chosen as TRV whenever available. This was the case for formaldehyde and $\mathrm{SO}_{2}$. Alternatively, guideline values proposed by the Nordic Committee on Building Regulations are applied (Nielsen et al., 1996; Nielsen et al., 1998) (organic acids, propanal, butanal, hexanal, octanal, and ammonia). Finally, tentative TRV are derived by dividing $0.03 \times \mathrm{RD}_{50}$ values by 10 (sensitive population) for pollutants where neither international nor national guideline values are available (acetaldehyde, pentanal, heptanal).

Table 1 summarises the guideline values (TRV) for the studied compounds.

Indoors, persons are typically exposed to mixtures of pollutants. Irritating effects of different compounds may possibly be additive at the low concentrations frequently encountered indoors. This assumption is supported by animal studies where irritating effects of mixtures of aldehydes at low concentrations were examined (Flemming et al., 1996).

According to this assumption, the resulting effect of a mixture may be expressed as a weighted sum parameter S (Equation 1), which contains the sum of pollutant 
concentrations $c_{i}$ divided by their corresponding $T R V_{i}$, expressing their irritation potential.

$$
S=\frac{c_{1}}{\operatorname{TR} V_{1}}+\frac{c_{2}}{\operatorname{TR} V_{2}}+\frac{c_{3}}{\operatorname{TR} V_{3}} \ldots<1
$$

If the weighted sum parameter $S$ is less than 1 , it is reasonable to assume that complaints about sensory irritation are not due to the presence of the compounds included in the studied mixture. Note however that $\mathrm{S}$ can also exceed 1 even when individual pollutant concentrations remain below their guideline values.

\section{Results and Discussion}

Relative humidity ranged between 28 and $49 \%$ (average 38\%) and remained for several days below the values recommended for a good indoor air quality $(40-50 \% \mathrm{RH})$. Pollutant concentrations for different sampling locations are summarised in Table 2. When only single spot measurements are available (e.g. organic acids), the results are considered to represent concentrations in all the sampling locations. Results are now compared with literature data and guideline values (Table 1).

$<$ Table 2 should be placed here. $>$

Average aldehyde concentrations agree well with existing literature data, and do not exceed their TRV in any case.

Organic acid concentrations are slightly above literature data, but remain below their TRV. 
Average $\mathrm{SO}_{2}$ concentrations are higher than concentrations presented in the literature.

Continous monitoring allowed for measuring $\mathrm{SO}_{2}$ during the occurrence of health complaints, but no peak concentrations were observed. $\mathrm{SO}_{2}$ concentrations remained below the TRV.

Ammonia concentrations remained below the TRV and are comparable to literature data.

$<$ Table 3 should be placed here. $>$

Other VOCs that were detected during a period with health complaints are summarised in Table 3 with relative intensities (relative to the most intensive peak) of the major constituents. A profile of compounds typically found indoors is obtained (Brown et al., 1994; Maroni et al., 1995). The identified compounds are not considered as particularly high sensory irritants.

\section{Risk Assessment}

The fundamental assumption of the sampling strategy consists in the fact that measured concentrations represent maximum concentrations to which all individuals can be exposed in all locations and at all times in the school. If this assumption is true, then the risk of developing sensory irritation due to the presence of the studied compounds can be assessed as negligible. This holds both for individual compounds (concentrations remain below the respective TRV) and for the mixture of studied compounds, as the weighted sum parameter $\mathrm{S}$ (Table 2) ranges between 0.2 and 0.5 and is hence less than 1.

\section{Conclusions}

The risk assessment of airborne sensory irritants present in the school leads to the conclusion that reported health complaints are not due to the presence of the measured compounds.

However, several aspects should be taken into account in this context: 
- The adopted sampling strategy may not be appropriate, since sampling time and location may not coincide with time windows and places where peak concentrations occurred. Online monitoring in all locations and of all potential sensory irritants would be necessary. This represents a challenge in terms of equipment and time, and online monitoring techniques are not available for all the compounds considered.

- With the existing sampling and analytical techniques it is not possible to sample, identify and quantify all sensory irritants which may be present in the air. In particular reactive compounds with one or more functional groups are rarely detected indoors, because of their short lifetime, and because conventional sampling and analytical techniques are not appropriate (Wolkoff et al., 1997; Wolkoff and Nielsen, 2001). New sampling and analytical techniques need to be developed.

- A reduced relative humidity and inadequate fresh air in the building may contribute to sensory irritation. Psychosocial factors can also play an important role in the given context: increased attention from authorities, the presence of 'experts' and sampling equipment, and a strong group behaviour will result in individuals paying much more attention to any health effect related to sensory irritation.

\section{References}

Alarie, Y., 1973. Sensory Irritation by Airborne Chemicals. Critical Reviews in toxicology, 2: 299-363.

Anderson, E.L. and Albert, R.E., 1999. Risk Assessment and Indoor Air Quality. Lewis Publishers, London - New York - Washington D.C. Bates, M., Gonzalez-Flesca, N., Sokhi, R. and Cocheo, V., 2000. Atmospheric Volatile Organic Compound Monitoring. Ozone Induced Artefact Formation. Environmental Monitoring and Assessment, 65: 89-97. 
Brown, S.K., Sim, M.R., Abramson, M.J. and Gray, C.N., 1994. Concentrations of Volatile Organic Compounds in indoor air - a review. Indoor Air, 4: 123.

Chao, C.Y.H., 2001. Comparison between indoor and outdoor air contaminant levels in residential buildings from passive sampler study. Building and Environment, 36: 9991007.

Cocheo, V., Boaretto, C. and Sacco, P., 1996. High Uptake Rate Radial Diffusive Sampler Suitable for Both Solvent and Thermal Desorption. Am. Ind. Hyg. Assoc. J, 57: 897-904.

Flemming, R.C., Arts, J.H.E., Groten, J.P. and Feron, V.J., 1996. Sensory irritation to mixtures of formaldehyde, acrolein, and acetaldehyde in rats. Arch. Toxicol., 70: 329337.

Gomzi, M., 1999. Indoor Air and respiratory health in preadolescent children. Atmospheric Environment, 33: 4081-4086.

Maroni, M., Seifert, B. and Lindvall, T., 1995. Indoor Air Quality - A Comprehensive Reference Book. Elsevier, Amsterdam.

Meininghaus, R. et al., 2001. Indoor and outdoor aldehyde concentrations in a mediumsized French town. In: G. Latini and C.A. Brebbia (Editors), AIR POLLUTION IX. WIT Press, Southampton, Boston, pp. 263-271.

Nazaroff, W.W. and Weschler, C.J., 2001. Indoor Air and the Public Good - Guest Editorial. Indoor Air, 11: 143-144.

Nielsen, G.D., Hansen, L.F., Nexoe, B.A. and Poulsen, O.M., 1996. Toxicological Based Air Quality Guidelines For Substances in Indoor Air, Nordic Committee on Building Regulations, NKB - Indoor Climate Committee.

Nielsen, G.D., Hansen, L.F., Nexoe, B.A. and Poulsen, O.M., 1998. Indoor Air Guideline Levels for Formic, Acetic, Propionic and Butyric Acid. Indoor Air, Supp. 5: 8-24.

Reiss, R., Ryan, P.B., Tibbetts, S.J. and Koutrakis, P., 1995. Measurement of Organic Acids, Aldehydes, and Ketones in Residential Environments and Their Relation to Ozone. Journal of the Air \& Waste Management Association, 45: 811-822. 
Ullrich, D., Gleue, C., Weiland, S. and Seifert, B., 1999. Indoor Air Concentrations of Aldehydes - A Field Study using DNPH Diffusive Sampling, Indoor Air'99. Proc. of the 8th International Conference on Indoor Air Quality and Climate, pp. 89.

WHO-OMS, 2000. Air Quality Guidelines for Europe, World Health Organization, Copenhagen.

Williams, I.D., Revitt, D.M. and Hamilton, R.S., 1996. A Comparison of Carbonyl Compound Concentrations at Urban Roadside and Indoor Sites. The Science of the Total Environment, 189/190: 475-483.

Wolkoff, P., Clausen, P.A., Jensen, B., Nielsen, G.D. and Wilkins, C.K., 1997. Are We Measuring the Relevant Indoor Pollutants? Indoor Air, 7: 92-106.

Wolkoff, P. and Nielsen, G.D., 2001. Organic compounds in indoor air - their relevance for perceived indoor air quality? Atmospheric Environment, 35: 4407-4417. 


\section{Table Captions}

Table 1: Target compounds, Toxicological Reference Values TRV and typical indoor concentrations. The TRV for heptanal is an estimate based on the TRV of its homologue pentanal. All TRV are rounded up in order to illustrate their approximate nature.

Table 2: Concentrations outdoors and in different sampling locations and weighted sum parameter $\mathrm{S}\left(\mu \mathrm{g} / \mathrm{m}^{3}\right)$. Organic acids and inorganic compounds were only measured in one classroom, these concentrations were hence extrapolated to other rooms

Table 3: Identified VOCs sampled during a period with sensory irritation (intensity relative to most intensive peak); +++ high intensity; ++ intermediate intensity; + low intensity 


\begin{tabular}{|c|c|c|c|c|}
\hline compound & CAS & $\begin{array}{l}\text { guideline value } \\
\left(\mu \mathrm{g} / \mathrm{m}^{3}\right) / \text { duration }\end{array}$ & $\begin{array}{c}\text { indoor air } \\
\text { concentration } \\
\text { range } \\
\left(\mu \mathrm{g} / \mathrm{m}^{3}\right)\end{array}$ & reference \\
\hline & & WHO (WHO-OMS, 2000) & & \\
\hline formaldehyde & $50-00-0$ & $100 / 30 \mathrm{~min}$ & $6-127$ & $\begin{array}{l}\text { (Meininghaus et } \\
\text { al., 2001) }\end{array}$ \\
\hline \multirow[t]{2}{*}{$\widehat{\mathrm{SO}_{2}}$} & $7446-09-5$ & $500 / 10 \mathrm{~min}$ & $3-12$ & (Chao, 2001) \\
\hline & & $\begin{array}{l}\text { Nordic Committee on } \\
\text { Building Regulations } \\
\text { (Nielsen et al., 1996; } \\
\text { Nielsen et al., 1998) }\end{array}$ & & \\
\hline formic acid & 64-18-6 & 2000 & $19-34$ & $\begin{array}{l}\text { (Reiss et al., } \\
\text { 1995) }\end{array}$ \\
\hline acetic acid & $64-19-7$ & 2500 & $39-72$ & $\begin{array}{l}\text { (Reiss et al., } \\
1995)\end{array}$ \\
\hline propionic acid & $79-09-4$ & 3000 & -- & \\
\hline butyric acid & $107-92-6$ & 4000 & -- & \\
\hline propanal & $123-38-6$ & 4000 & $3-5$ & $\begin{array}{l}\text { (Reiss et al., } \\
1995)\end{array}$ \\
\hline butanal & $123-72-8$ & 3000 & $1-2$ & $\begin{array}{l}\text { Reiss et al., } \\
\text { 1995; Ullrich et } \\
\text { al., 1999) }\end{array}$ \\
\hline hexanal & $66-25-1$ & 3000 & $3-92$ & $\begin{array}{l}\text { (Meininghaus et } \\
\text { al., 2001) }\end{array}$ \\
\hline octanal & $124-13-0$ & 4000 & $1.5-29$ & $\begin{array}{l}\text { (Meininghaus et } \\
\text { al., 2001; Ullich } \\
\text { et al., 1999) }\end{array}$ \\
\hline \multirow[t]{2}{*}{$\mathrm{NH}_{3}$} & $7664-41-7$ & 4000 & $0-423$ & (Gomzi, 1999) \\
\hline & & Tentative & & \\
\hline acetaldehyde & $75-07-0$ & 20000 & $3-86$ & $\begin{array}{l}\text { (Meininghaus et } \\
\text { al., 2001; Williams } \\
\text { et al., 1996) }\end{array}$ \\
\hline pentanal & $110-62-3$ & 12000 & $1-6$ & $\begin{array}{l}\text { (Meininghaus et } \\
\text { al., 2001) }\end{array}$ \\
\hline heptanal & $111-71-7$ & 12000 (estimate) & $3-17$ & $\begin{array}{l}\text { (Meininghaus et } \\
\text { al., 2001) }\end{array}$ \\
\hline
\end{tabular}




\begin{tabular}{|c|c|c|c|c|c|c|c|}
\hline & \multicolumn{7}{|c|}{ Concentrations of sensory irritants in different locations $\left(\mu \mathrm{g} / \mathrm{m}^{3}\right)$} \\
\hline & outdoors & dormitory & |class I & class II & class III & hall & office \\
\hline Formaldehyde & 2 & 20 & 22 & 25 & 23 & 22 & 23 \\
\hline Acetaldehyde & 2 & 6 & 6 & 7 & $\overline{6}$ & 6 & 7 \\
\hline Propanal & & & & - & & - & - \\
\hline Butanal & - & 4 & 3 & 4 & 4 & 3 & 6 \\
\hline Pentanal & & & - & & - & - & - \\
\hline Hexanal & 1 & 6 & 8 & 11 & 7 & 4 & 5 \\
\hline Heptanal & & & & & - & - & - \\
\hline Octanal & 1 & 4 & - & - & 1 & - & 1 \\
\hline formic acid & 55 & 26 & 26 & 26 & 26 & 26 & 26 \\
\hline acetic acid & - & 65 & 65 & 65 & 65 & 65 & 65 \\
\hline Ammonia & 312 & 312 & 312 & 312 & 312 & 312 & 312 \\
\hline $\mathrm{SO}_{2}$ & 42 & 42 & 42 & 42 & 42 & 42 & 42 \\
\hline sum $S$ & 0.2 & 0.4 & 0.4 & 0.5 & 0.4 & 0.4 & 0.4 \\
\hline
\end{tabular}




\begin{tabular}{|l|l|}
\hline compound & intensity \\
\hline benzene & + \\
\hline toluene & ++ \\
\hline 2 ethyl hexanol & +++ \\
\hline ethyl hexanoic acid & ++ \\
\hline ethyl benzene & + \\
\hline xylenes & + \\
\hline terpenes & + \\
\hline phenol & + \\
\hline dichlorobenzene & + \\
\hline
\end{tabular}

